\title{
Standardization of Polymerase Chain Reaction Assay for the Authentication of Arapaima gigas fish
}

\author{
Wanessa Shuelen Costa Araújo \\ Doctoral student in Science and Food Technology, Programa de Pós-graduação em Ciência e \\ Tecnologia de Alimentos, Universidade Federal do Pará, UFPA, Rua Augusto Correa, n.1, \\ Bairro Guamá, CEP 66075110 Belém, PA. E-mail: araujo_wanessa@ hotmail.com
}

\section{Carina Martins Moraes}

Prof. Dra. Programa de Pós-Graduação em Saúde Animal na Amazônia, Faculdade de Medicina Veterinária, Universidade Federal do Pará, UFPA, Av. dos Universitários Jaderlândia, CEP 68746-360, Castanhal-PA. E-mail: carina_morais@terra.com.br

\section{Vanderson Vasconcelos Dantas}

Doctoral student in Science and Food Technology, Programa de Pós-graduação em Ciência e Tecnologia de Alimentos, Universidade Federal do Pará, UFPA, Rua Augusto Correa, n.1, Bairro Guamá, CEP 66075110 Belém, PA. E-mail: vd_dantas@ hotmail.com

\section{Andrey Carlos Sacramento de Oliveira}

Doctoral Student in Saúde Animal na Amazônia, Programa de Pós-Graduação em Saúde Animal na Amazônia, Faculdade de Medicina Veterinária, Universidade Federal do Pará (UFPA), Av. dos Universitários - Jaderlândia, CEP 68746-360, Castanhal-PA.

E-mail: andrey.oliveira@zootenista.com.br

\section{Talita Bandeira Roos}

Prof. Dr. Programa de Pós-Graduação em Saúde Animal na Amazônia, Faculdade de Medicina Veterinária, Universidade Federal do Pará, UFPA, Av. dos Universitários Jaderlândia, CEP 68746-360, Castanhal-PA. E-mail: talitaroos@ufpa.br

\section{Luiza Helena da Silva Martins}

Prof. Dr. do ISPA (Instituto de Saúde e Produção Animal), Universidade Federal da Amazônia, UFRA, Avenida Presidente Tancredo Neves, n. 2501. Bairro Terra Firme, CEP 66.077-830, Belém, Pará, Brazil. E-mail: luiza.martins @ufra.edu.br. 
Lúcia de Fátima Henriques Lourenço (Corresponding author)

Profa. Dra. Programa de Pós-Graduação em Ciência e Tecnologia de Alimentos, Faculdade de Engenharia de Alimentos, UFPA, Rua Augusto Correa, n.1, Bairro Guamá, CEP 66075110 Belém, PA. https://orcid.org/0000-0001-5009-8235, E-mail: luciahl@ufpa.br

Received: May 5, 2020

doi:10.5296/jas.v8i2.16962
Accepted: June 1, 2020

Published: June 4, 2020

URL: https://doi.org/10.5296/jas.v8i2.16962

\begin{abstract}
Pirarucu is a freshwater fish that presents a great commercial value for being well accepted by the consumers and for showing excellent meat quality. The zoological identification of fisheries during industrial processing is harmed by the removal of external morphologic characteristics, facilitating fraudulent practices in commercialization. In this context, the identification at the molecular level is an important tool in the inspection and commercialization of the fishery. The DNA resists to the processing methods, like the salting, the most common way of commercializing the pirarucu. The Polymerase chain reaction, PCR assay, were applied in samples that suffered degradation or have gone under industrialization methods. This work aimed use the PCR technique as a tool to authenticate the Arapaima gigas species and to avoid possible frauds in commercially available products. The obtained data showed the efficiencies of the DNA extraction, the amplification of the target sequence, and identification of the genetic material through PCR. It is possible to conclude that the PCR technique that was standardized in the present study showed high sensibility, precision, and specificity for the detection of the genetic material of Arapaima gigas, constituting a useful tool for the monitoring and inspection during its commercialization.
\end{abstract}

Keywords: fish, fraud, pirarucu, PCR

\title{
1. Introduction
}

Arapaima gigas (Schinz, 1822) is a member of the Order Osteoglossiform and family Osteoglossidae and it is popularly known in Brazil as pirarucu. In other regions, this fish is called by different names, like bodecos (high Amazonas) and paiche (Peru and Ecuador). Its distribution is referenced in South America (Amazon Basin and Guyana rivers), and it can be found in Brazil, Colombia, Guyana, Peru and Ecuador, where native species occur (Rosa et al., 2020).

Pirarucu is considered the largest freshwater fish with scales in the world and it can grow up to four meters of length and $200 \mathrm{~kg}$ of body mass (Chu-Koo et al., 2008). This fish inhabits mainly lowland lakes and flooded forests (Castello, 2008). In Amazon, its consumption is a traditional habit that has expanded to other regions and countries (Santos-Cipriano, 2015). Its collection in the Amazonian region has relevant ecological and socio-cultural functions, 
representing economic and nourishing importance since the colonial times, especially due to the meat flavor, the nutritional value and the commercial value.

These characteristics increase its vulnerability in terms of conservation, leading this species to show signs of overfishing (Campos-Silva and Peres, 2016; Begossi et al., 2018). This fish also presents great potential to aquiculture due to its characteristics that are favorable to the creation, like rapid growth, the capacity of aerial respiration, easy adaptation to feed, the meat of high quality, and great income (Paiva, 2015; Santos-Cipriano, 2015). The potential aquiculture can make the species get out of the overfishing situation, increasing its production and commercialization such in the internal market as in the external market.

The Arapaima gigas species is also known as "cod of the Amazon" and it is commercialized mainly in in salting and dry form. However, this processing of this fish is still rudimentary (Nunes et al., 2012). In salting processing, there is the removal of morphological characteristics (skin and head), because it makes the species hard to be identified and increases the chances of adulteration and mistakes in the labeling (Brito et al., 2015).

The frauds in the food can be in many ways: alterations, adulterations, and falsification, which are done with the goal of obtaining higher profits. This practice is generally adopted when there are accentuated differences in the price or in the availability of products (Fox et al., 2018). This situation may be occurring with the pirarucu (Arapaima gigas) commercialization in the north region of Brazil, once its predatory fishing has decreased the natural stock.

Considering the losses that the frauds can cause, the existence of tools to detect and identify the different species of commercially available fish is necessary. Currently, the existing methods of identification are be based on the morphologic and anatomic analysis of the muscles, on the protein analysis with electrophoresis and on the analysis of the lipids. However, although these methods are cheap and fast, they use proteins and lipids for their development and these compounds can be denatured or degraded during the food processing (heating, conserving or drying), producing alterations in the obtained results (Hsieh et al., 2010; Dalama et al., 2015).

In this context, an alternative for food authentication that was studied by many authors is the Polymerase Chain Reaction (PCR). The PCR is a technique that amplifies a DNA template to produce specific DNA fragments in vitro, allowing the detection of genetic material, even in low quantities. This method presents advantages like speed, high sensitivity, and specificity, besides being able to detect DNA regardless of its fount, showing more efficiency than techniques like chromatography and electrophoresis (Mayer, 2005; Dalmasso et al., 2011). The PCR is a useful tool for the monitoring and inspection of food destined for human consumption.

Several studies used the PCR for detection of frauds in fish and other products of animal origin (Aguilar et al., 2012; Khallaf et al., 2014; Ali et al., 2015; Brito et al., 2015; Mousavi et al., 2015; Mueller et al., 2015; Safdar and Junejo, 2015; Sumathi et al., 2015; Tisza, et al., 2016). Although this technique was applied on the identification of several species, there is 
still few information on the applicability of this method in the detection of fraudulent changes in fish and fish-derived products (Mousavi et al., 2015).

Considering all this information, the present study aimed to standardize a PCR for the authentication of pirarucu (Arapaima gigas) that can be used as a tool to prevent possible frauds in commercially available products.

\section{Material and Methods}

\subsection{Raw Material}

Samples of pirarucu (Arapaima gigas) were acquired in Tefé, Amazonas - Brazil. Samples of black caiman (Melanosuchus niger), pantanal alligator (Caiman crocodilus), gillbacker sea catfish (Hexanematichthys parkeri), acoupa weakfish (Cynoscion acoupa), school shark (Galeorhinus galeus), meagre (Argyrosomus regius), kumakuma (Brachyplathystoma filamentosum), dourada (B. rousseauxii), laulao catfish (B. vaillant), crevalle jack (Caranx hippos), smooth weakfish (Cynoscion leiarchus) and common stingray (Dasyatis guttata) were collected in municipality of Castanhal (1 $\left.{ }^{\circ} 17^{\prime} 27.8^{\prime \prime S} 47^{\circ} 55^{\prime} 23.0^{\prime \prime} \mathrm{W}\right)$, state of Pará, Brazil. The collected material was forwarded to the Laboratory $\left(1^{\circ} 18^{\prime} 42.6^{\prime \prime} \mathrm{S} 47^{\circ} 56^{\prime} 49.9^{\prime \prime} \mathrm{W}\right)$, and it was stored under freezing at $-16^{\circ} \mathrm{C}$ until the execution of the proposed methodology.

\subsection{DNA Extraction}

The DNA samples were extracted, following the protocol validated by Darwish et al. (2009), with modifications suggested by Oliveira et al. (2015). The changes were carried out in the initial step of the protocol, where fractions of $0.3 \mathrm{~g}$ of the sample was macerated and added with lysis buffer STES (0.2 M of Tris base, $0.5 \mathrm{M}$ of sodium chloride, $0.1 \%$ (w/v) of Sodium Dodecyl Sulfate and $0.01 \mathrm{M}$ of Ethylenediaminetetraacetic Acid). The material was homogenized in an orbital shaker, and it was incubated in a stove at $56^{\circ} \mathrm{C}$ overnight with $10 \mu \mathrm{L}$ of proteinase $\mathrm{K}\left(20 \mathrm{mg} \mathrm{mL}^{-1}\right)$. The other parts of the sample processing were performed according to the original protocol (Darwish et al., 2009); the DNA was extracted eluted in 25 $\mu \mathrm{L}$ of TRIS-EDTA (TE) buffer, $\mathrm{pH}$ 8.0.

After all the related procedures, the obtained DNA was quantified in spectrophotometer BioTek ${ }^{\circledR}$ Gen $5^{T M}$ and absorbance measurements were performed at $280 \mathrm{~nm}$ and at $230 \mathrm{~nm}$ in order to verifying the purity of the samples. The $280 \mathrm{~nm}$ length corresponded to the absorption peak of ultraviolet (UVs) rays and the $230 \mathrm{~nm}$ length corresponded to the absorption peak of UVs from organic contaminants, according to Lambert-Beer law (Lambert, 1760; Beer, 1852).

Specific initiators for the Arapaima gigas (Primer forward 5' TCACACGATGGGGCAATCAA3' and Primer reverse 5' TGTCGTAAGCAGATCGAGCC 3') were used. The primers were designed with the PRIMER-BLAST tool, provided by the NCBI (National Center for Biotechnology Information) and they amplified sequences of 439 base pairs (bp). The design was made from the sequence obtained through the gene bank, which refers to the complete mitochondrial genome from the studied fish. The oligonucleotides were prepared following the instruction of the manufacture (Ludwing 
Biotec $\left(\right.$ ) and eluted in buffer TE pH 8.0 until the concentration of 100 pmol $\mu \mathrm{L}^{-1}$.

Tests to establish the ideal temperature of annealing were carried out in order to to determine the efficiency of the produced primers. For that, five temperatures $\left(52^{\circ} \mathrm{C}, 53^{\circ} \mathrm{C}, 54^{\circ} \mathrm{C}, 55^{\circ} \mathrm{C} \mathrm{e}\right.$ $56^{\circ} \mathrm{C}$ ) were performed and the selection was carried out through visual evaluation of the band patterns regarding the intensity.

The utilized PCR solution was calculated for a final volume of $25 \mu \mathrm{L}$ for each reaction. For that, there were utilized $50 \mathrm{nM}$ of $\mathrm{KCl}$ and $10 \mathrm{mM}$ Tris- $\mathrm{HCl}$ (buffer $1 \mathrm{X}$ ), $10 \mathrm{nM}$ dNTP mix, approximately $1.6 \mathrm{ng}$ of DNA mold, 1U Taq DNA Polymerase, 10 pmol of each initiator and the volume was completed with MiliQ water. The Thermocycler was programmed to 30 cycles and the temperatures and times utilized to denaturation, annealing and extension were $93^{\circ} \mathrm{C}_{30 \mathrm{~s}^{-1}}$, from 52 to $56^{\circ} \mathrm{C} 30 \mathrm{~s}^{-1}$ and $72^{\circ} \mathrm{C}^{\circ} 0 \mathrm{~s}^{-1}$, respectively, increased by initial denaturation at a temperature of $93^{\circ} \mathrm{C} 3 \mathrm{~min}^{-1}$ and a final extension at $72^{\circ} \mathrm{C} 10 \mathrm{~min}^{-1}$.

The visualization of the amplified material was performed through electrophoresis in agarose gel at $1.5 \%$, utilizing $1 \mu \mathrm{L}$ of Safer colorant $(6 \mathrm{X})$ for each $5 \mu \mathrm{L}$ of the sample. The electrophoresis was conducted in a horizontal tank containing TBE 0.5X (89 nM Tris- $\mathrm{HCl}, 89$ $\mathrm{nM}$ of boric acid and $20 \mathrm{nM}$ of EDTA), with amperage of $90 \mathrm{~A}$. The analysis of the electrophoresis results was performed with the help of an equipment of photo documentation under ultraviolet light (Gel Documentation System, Gel Doc ${ }^{\mathrm{TM}}$, Bio-Rad®).

The evaluation of the PCR analytic sensitivity was performed from the serial dilution of DNA previously extracted and quantified. For that, ten microtubes were prepared, in triplicate, for serial dilution and each one contained $90 \mu \mathrm{L}$ of sterilized Milli Q water. This way, dilutions from $10^{-1}$ to $10^{-10}$ were obtained. Besides these ones, the dilutions 1:1 and 1:4 were also tested. The DNA solutions, as well as their respective dilutions, were submitted to the proposed PCR. The target-DNA threshold detection was based on the last dilution that presented band visualization (PCR product) in electrophoresis. The technique of sensitivity threshold was calculated through the ratio between the concentration of the minor amplified dilution and the concentration of the utilized DNA; this value was expressed in percentage, according to what was previously suggested by Brodmann and Moor (2003).

The specificity of the initiators was tested concerning to the presence of genomic material from other species of fish commercialized in the Amazon region. For that, the DNAs from 12 species were utilized: Melanosuchus niger, Caiman crocodilus, Hexanematichthys parkeri, Cynoscion acoupa, Galeorhinus galeus, Argyrosomus regius, Brachyplathystoma filamentosum, B. rousseauxii, Caranx hippos, B. vaillant, Cynoscion leiarchus andDasyatis guttata. Five repetitions of the DNA extraction of each species and five repetitions of the amplification reactions were performed, all under the same conditions.

\section{Results and Discussion}

The observed results showed that the DNA was obtained with enough quality and concentrations for the PCR execution with the proposed methodology. The purity and the yield of the total extracted DNA were verified through measurement of absorbance at $230 \mathrm{~nm}$, $260 \mathrm{~nm}$ and $280 \mathrm{~nm}$, which indicated values with purity parameters and medium DNA 
concentration in the samples of $1.6 \mathrm{ng} \mu \mathrm{L}^{-1}$.

The protocol that was used in the present study, adapted from Darwish et al. (2009) proved to be effective in all the tested dilutions. This result can be related to the use of Proteinase K, which has been utilized in several extraction protocols due to its protein degradation action in different samples, even in the presence of detergents. Although the technique used in the present study has been very efficient in the DNA extraction, many authors refer to the DNA extraction as a critical step during the food analysis, mainly in the most processed products. Some factors, such as DNA degradation, matrix effect, and presence of PCR inhibitors, imply a low limit of detection or quantification.

The food analysis presents some difficulties because it can contain interferers in its composition, such as proteins, polysaccharides, fat, salt, colorants, and others. Besides that, the use of physical and chemical treatments may predispose the DNA fragmentation, which blocks its utilization in the PCR (Marcelino et al., 2008; Cardoso et al., 2019). The extraction methodology proposed has been utilized by several researchers for the obtainment of DNA from milk, cheese and meat samples (Colgan et al., 2001; Brodmann, and Moor 2003; Kesmen et al., 2007; Kesmen et al., 2009; Amaral et al., 2014; Karabasanavar et al., 2014; Dantas et al., 2019). However, until the moment of this study, this methodology were not utilized for a fishery. In this way, our results point out a viable alternative to the DNA extraction of fish, which can be tested in studies that utilize another species besides Arapaima gigas.

The test that evaluated the ideal annealing temperature of the initiators showed that the designed primer was capable of annealing the target-DNA at the five analyzed temperatures. Based on this result, the temperature of $55^{\circ} \mathrm{C}$ was elected the more suitable one, since it presented a clearer band with 439 base pairs in agarose gel at $1.5 \%$, as it is seen in Figure 1B.

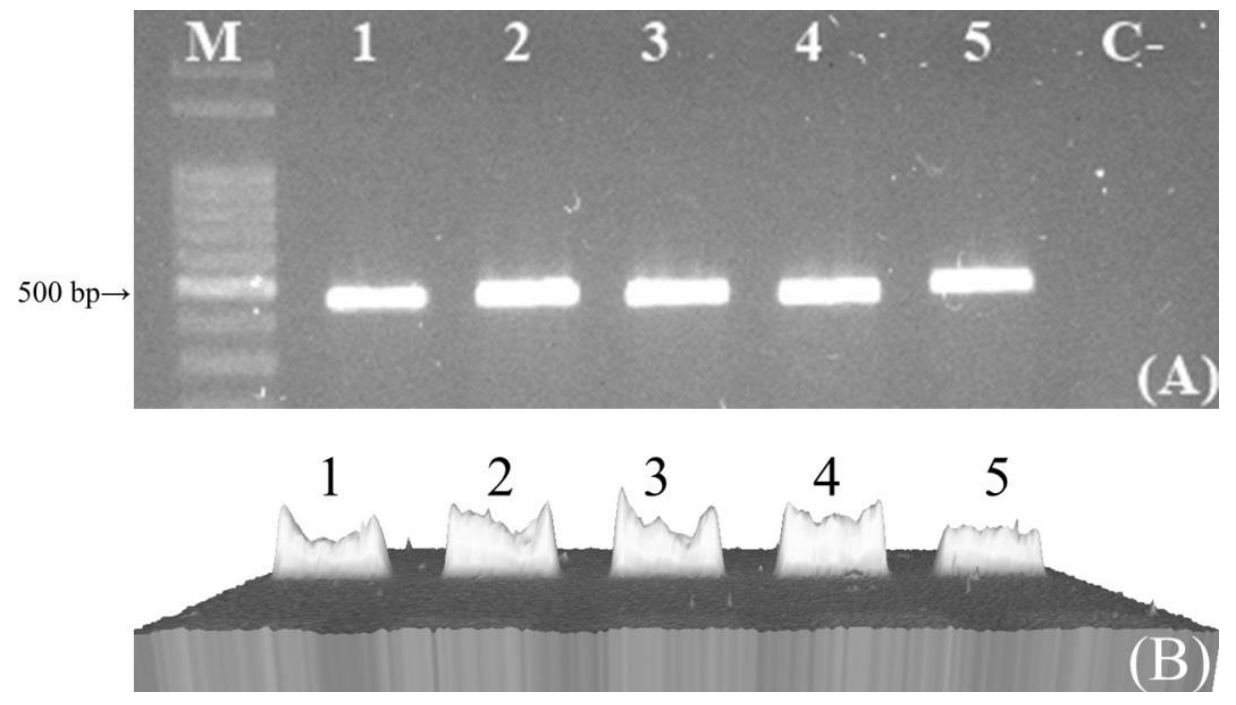

Figure 1. (A) Agarose gel 1.5\%, colored with Safer, showing the presence of bands (439bp) specific to the Arapaima gigas species, obtained through PCRs with annealing temperatures varying from $52^{\circ} \mathrm{C}$ to $55^{\circ} \mathrm{C}$ 
M: molecular marker $1 \mathrm{~kb} ; 1$ to 5: obtained bands through PCR with annealing temperatures of $52^{\circ} \mathrm{C}, 53^{\circ} \mathrm{C}, 54^{\circ} \mathrm{C}, 55^{\circ} \mathrm{C}$ and $56^{\circ} \mathrm{C}$ and negative C-Control. (B) 3D Demonstration of Arapaima gigas' DNA fragments amplification (439bp), obtained through PCRs with different annealing temperatures, generated by Gel Doc XR+ from Bio rad with software Image Lab Version 5.2.1.; 1 to 5: bands obtained through PCR with annealing temperatures of $53^{\circ} \mathrm{C}, 54^{\circ} \mathrm{C}, 55^{\circ} \mathrm{C}$ and $56^{\circ} \mathrm{C}$

Until this moment, literature does not present primers for the Arapaima gigas species. The primers proposed in this study are efficient and capable of annealing at a wide range of temperatures, which proves the viability of their utilization in the detection of frauds and in multiplex reactions in future studies. This technique increases the information content by ge1, decreases the time spent, which reduces the costs for the PCR around 50\%, and the costs for the agarose gel around $85 \%$ when compared to the conventional procedure (Masi et al., 2003).

The analytical sensitivity test for PCR showed that the technique used in this study was capable of amplifying DNA fragments of Arapaima gigas until the dilution $10^{-2}$ $\left(0.016 \mathrm{ng} / \mu \mathrm{L}^{-1}\right)$, as it is shown in Figure 2. The technique presented sensitivity threshold of $1 \%$, justifying its utilization as a method of authentication for the species. Therefore, the dilutions $1: 1,1: 4,10^{-1}, 10^{-2}, 10^{-3}, 10^{-4}, 10^{-5}, 10^{-6}, 10^{-7}, 10^{-8}, 10^{-9}, 10^{-10}$ corresponded to the concentrations of $0.8 \mathrm{ng} \mu \mathrm{L}^{-1}, 0.4 \mathrm{ng} \mu \mathrm{L}^{-1}, 0.16 \mathrm{ng} \mu \mathrm{L}^{-1}, 0.016 \mathrm{ng} \mu \mathrm{L}^{-1}, 0.0016 \mathrm{ng} \mu \mathrm{L}^{-1}, 0.00016$ $\mathrm{ng} \mu \mathrm{L}^{-1}, 0.016 \rho g \mu \mathrm{L}^{-1}, 0.0016 \rho g \mu \mathrm{L}^{-1}, 0.00016 \rho g \mu \mathrm{L}^{-1}, 0.016 \mathrm{fg} \mu \mathrm{L}^{-1}, 0.0016 \mathrm{fg} \mu \mathrm{L}^{-1}, 0.00016$ fg $\mu \mathrm{L}^{-1}$, respectively.

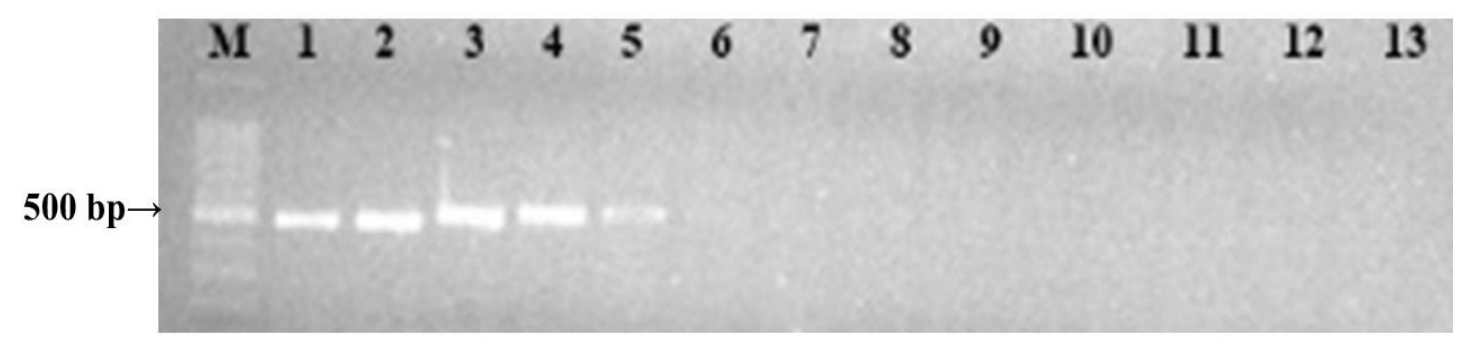

Figure 2. Agarose gel 1.5\% colored with Safer demonstrated presence of DNA fragments of Arapaima gigas (439bp), obtained through PCR of different DNA dilutions

M: Molecular marker 1kb, 1: DNA at 1.6ng $\mu \mathrm{L}^{-1}, 2$ : Dilution 1:11 (0.8ng $\left.\mu \mathrm{L}^{-1}\right)$, 3: Dilution 1:4 $\left(0.4 \mathrm{ng} \mu \mathrm{L}^{-1}\right)$, 4: Dilution $10^{-1}$, 5: Dilution $10^{-2}, 6$ : Dilution $10^{-3}$, 7: Dilution 10 $0^{-4}$, 8: Dilution $10^{-5}$, 9: Dilution $10^{-6}$, 10: Dilution $10^{-7}$, 11: Dilution $10^{-8}$, 12: Dilution $10^{-9}$ and 13: Dilution $10^{-10}$.

Researches that also performed authentication for other food of animal origin obtained results similar to the present study. Sultana et al. (2018), while evaluating the sensitivity of specific DNA initiators from bovines, porcine, and fishes, obtained a detection limit of $0.1 \%$ to $0.001 \%$ for the specific initiators.

Researches like the one of Karabasanavar et al. (2014), who performed a PCR assay to detect adulteration in pork, showed detection levels of $0.01 \%$ when evaluating the sensitivity of the 
technique from series dilutions. Amaral (2014) performed a study to authenticate the sausage and evaluated the sensitivity of the technique. The detection levels obtained were $0.01 \%$ for the DNAs of rabbit, cow and hare and $0.1 \%$ for the DNAS of dear, pork, and red meat. Hossain (2019) researched the presence of cow, buffalo, chicken, cat, dog, swine, and fish in raw and processed foods, obtained a sensitivity threshold of $0.001 \%$ for raw food and $0.5 \%$ for Heat-Treated Food Products.

In the analytical specificity test of PCR (Figure 3), it was verified that there were no cross-reactions in the DNA amplification when comparing the 12 non-target species that were analyzed, proving the specificity of this technique for the detection of genetic material from Arapaima gigas. The precision of the PCR was also evaluated and after the performance of five repetitions from the referred assay utilizing DNA from five different extractions of the twelve evaluated species, it was verified that the results were identical, proving the precision of the method.

\section{$\begin{array}{lllllllllllllll}\mathrm{M} & \mathrm{C}+ & 1 & 2 & 3 & 4 & 5 & 6 & 7 & 8 & 9 & 10 & 11 & 12 & \mathrm{C} .\end{array}$}

$500 \mathrm{bp}$

Figure 3. Agarose gel 1.5\%, colored with Safer, showing one of the repetitions from the specificity test for the primers that weredesigned for the authentication of Arapaima gigas

M: molecular marker $1 \mathrm{~kb}, \mathrm{C}+$ : Band of $439 \mathrm{bp}$, correspondent to Aparaima gigas (positive control); 1: PCR of Melanosuchus niger DNA; 2: PCR of Caiman crocodilus DNA; 3: PCR of Hexanematichthys parkeri DNA; 4: PCR of Cynoscion acoupa DNA; 5: PCR of Galeorhinus galeus DNA; 6: PCR of Argyrosomus regius DNA; 7: PCR of Brachyplathystoma filamentosum DNA; 8: PCR of B. rousseauxii DNA; 9: PCR of Caranx hippos DNA; 10: PCR of B. vaillant DNA; 11: PCR of Cynoscion leiarchus DNA; 12: PCR of Dasyatis guttata DNA and C: negative control.

The specificity obtained by PCR in this study was high and was compared to the values obtained in other studies, as the one performed by Karabasanavar et al. (2014), who carried out a PCR assay to detect adulterations in pork and tested their initiators in other 24 species of animals. These authors verified that the animals presented high level of specificity for the initiator with the target sequence. Colgan et al. (2001), besides the pork, also developed a PCR to identify beef, ovine meat and poultry meat and verified, after specificity test, that the utilized initiators were specific for each target species.

In same way, Kesmen et al. (2007) and Amaral et al. (2014) performed authentication assays in sausages. Kesmen et al. (2007) tested the specificity of each one of the species-specific initiators, confirming amplification in bovine, ovine, equine, asinine, and swine. Amaral et al. (2014) evaluated the specificity of their initiators testing the PCR amplification for other animal species ordinarily utilized as food, like boar, duck, pheasant, poultry, ostrich, caprine, 
ovine, and confirmed the specificity of the initiators designed for the Bostaurus with $100 \%$ of identity.

In the same context, Colgan et al. (2001), while developing a PCR for the identification of bovine, ovine, swine and poultry meat, verified, after specificity test, that the utilized initiators were specific for each target species. Still, Kesmen et al. (2009), who performed an experiment for the identification of equine, asinine and pork meat, tested their initiators for 7 types of meat (bovine, swine, equine, donkey, ovine, chicken and turkey), and also concluded that the specific initiators for the species of donkey and swine did not show any cross-reaction, proving its specificity.

Since there are no designed primers commercially available for the species Arapaima gigas, the present study designed and tested for the first time this technique. The quality of the initiators was fundamental for the PCR success, for these were capable of identifying the target species with exactitude and presented specific bands for the analyzed species without showing cross-reactions or dimer formations, which validates its precision. The technique also proved to be highly sensitive and this result is compatible with the ones reported by several authors like Colgan et al. (2001), Brodmann and Moor (2003), Kesmen et al. (2007), Kesmen et al. (2009), Amaral et al. (2014), Karabasanavar et al. (2014). In this way, the results obtained in the present study prove that the proposed technique may be an important tool in the monitoring and inspection of the species Arapaima gigas.

Although the presented data are extremely relevant, more studies aiming the authentication of samples obtained in the commerce must be performed, in order to take the proposed methodology to a quotidian use in different conditions than the ones proposed in this experiment. The use of PCR is already widespread in studies of several food-products of animal origin. However, there are few studies regarding the authentication of fish and fish-derived products. These studies are extremely important, once the processing of the products eliminates morphological features, facilitating fraudulent practices in processed fishery, which is the case of the species Arapaima gigas.

Considering the wide variety of fish species and derived products, the flaws in the inspection of these products' commercialization that facilitates their fraudulence and the small number of published researches regarding the fishery authentication, this study demonstrated as a methodologic base for the performance of new researches with another species of fish.

\section{Conclusion}

The initiators proposed in this study present high sensitivity, precision and specificity thresholds for the detection of genetic material from pirarucu (Arapaima gigas), proving that the proposed PCR technique was standardized with success. The PCR represents an excellent alternative for the detection of frauds caused by the replacement of pirarucu for other species, and constitutes a useful tool for the authentication of this product by the official entities of inspection. 


\section{References}

Aguilar, A., Alonso, G., \& Barrero, M. (2012). Identification of commercial species of tuna (Thunnus spp) in Venezuela using the PCR technique. Revista Cientifica, 22, 368-375.

Ali, M. E., Razzak, M. A., Hamid, S. B.A., Rahman, M. M., Amin, M. A., Rashid. N. R. A., \& Asing. (2015). Multiplex PCR assay for the detection of five meat species forbidden in $\begin{array}{lllll}\text { Islamic foods. Food } & \text { 214-224. }\end{array}$ https://doi.org/10.1016/j.foodchem.2014.12.098

Amaral, J. S., Santos, C. G., Melo, V. S., Oliveira, M. B. P., \& Mafra, I. (2014). Authentication of a traditional game meat sausage (Alheira) by species-specific PCR assays to detect hare, rabbit, red deer, pork and cow meats. Food Research International, 60, 140-145. https://doi.org/10.1016/j.foodres.2013.11.003

Beer, A. (1852). Bestimmung der Absorption des rothen Lichts in farbien Flüssigkeiten. Annalen der Physik, 152, 78-82. Accessed on: February 2020 https://doi.org/10.1002/andp.18521620505

Begossi, A., Salivonchyk, S. V., Hallwass, G., Hanazaki, N., Lopes, P. F. M., Silvano, R. A. M., ... Pittock, J. (2018). Fish consumption on the Amazon: a review of biodiversity, hydropower and food security issues. Brazilian Journal Biology, 79, 345-357. https://doi.org/10.1590/1519-6984.186572

Brito, M. A., Schneider, H., Sampaio, I., \& Santos, S. (2015). DNA barcoding reveals high substitution rate and mislabeling in croaker fillets (Sciaenidae) marketed in Brazil: The case of "pescada branca" (Cynoscion leiarchus and Plagioscion squamosissimus). Food Research International, 70, 40-46. https://doi.org/10.1016/j.foodres.2015.01.031

Brodmann, P. D., \& Moor, D. (2003). Sensitive and semi-quantitative Taq Man TM real-time polymerase chain reaction systems for the detection of beef (Bos taurus) and the detection of the family Mammalia in food and feed. Meat Science, 65, 599-607. https://doi.org/10.1016/S0309-1740(02)00253-X

Campos-Silva. J. V., \& Peres, C. A. (2016). Community-based management induces rapid recovery of a high value tropical freshwater fishery. Scientific Reports, 6, 1-13. https://doi.org/10.1038/srep34745

Cardoso, G. V. F., Oliveira, A. C. S., Silva, A. S., Araújo, W. S. C., Dantas, V. V., Silva, J. B., ... Moraes, C. M. (2019). Detection of fraud by addition cow's milk in cheese buffalo and its connection with seasonality. Revista Brasileira de Ciências Veterinárias, 26, 152-157. https://doi.org/10.4322/rbcv.2019.027

Castello, L. (2008). Nesting habitat of pirarucu Arapaima gigas in flood plains of the Amazon. Journal of Fish Biology, 72, 1520-1528. https://doi.org/10.1111/j.1095-8649.2007.01778.x

Chu-Koo, F., Dugué, R., Alván, A. M., Casanova, D.A., Alcántara Bocanegra, F., Chávez, V. C., \& Nuñez, J. (2008). Gender determination in the paiche or pirarucu (Arapaimagigas) using plasma vitellogenin, 17b-estradiol, and 11-ketotestosterone levels. Fish Physiology and 
Biochemistry, 35, 25-136. https://doi.org/10.1007/s10695-008-9211-8

Colgan, S., O’Brien, L., Maher, M., Shilton, N., Mcdonnell, K., \& Wars, S. (2001). Development of a DNA-based assay for species identification in meat and bone meal. Food Research International, 34, 409-414. https://doi.org/10.1016/S0963-9969(00)00185-X

Dalama, J., Vieites, J. M., \& Espeñeira, M. (2015). Detection of the causal agents of Keriorrhea (Lepidocybium flavobrunneum and Ruvettus pretiosus) by means of Real Time PCR. Food Chemistry, 174, 326-329. https://doi.org/10.1016/j.foodchem.2014.11.070

Dalmasso, A., Civera, T., Neve, L., \& Bottero, M. T. (2011). Simultaneous detection of cow and buffalo milk in mozzarella cheese by Real-Time PCR assay. Food Chemistry, 124, 362-366. https://doi.org/10.1016/j.foodchem.2010.06.017

Dantas, V. V., Cardoso, G. V. F., Araujo, W. S. C., Morais, C. M., \& Lourenço, L. F. H. (2019). Application of a multiplex polimerase chain reaction (mPCR) assay to detect fraud by substitution of bovine meats cuts with water buffalo meat Nortem Brazil. Cyta Journal of Food, 17: 790-795. https://doi.org/10.1080/19476337.2019.1650832

Darwish, S. F., Allam, H. A., \& Amin, A. S. (2009). Evaluation of PCR assay for direction of cow's Milk in water buffalo's milk. World Applied Sciences Journal, 7, 461-467.

Fox, M., Mitchell, M., Dean, M., Elliott, C., \& Campbell, K. (2018). The seafood supply chain from a fraudulent perspective. Food Security, 10, 939-963. https://doi.org/10.1007/s12571-018-0826-Z

Hossain, M. A. M., Uddin, S. M. K., Sultana, S., Bonny, S. Q., Khan, M. F., Chowdhury, Z. Z., ... Ali, M. E. (2019). Heptaplex polymerase chain reaction assay for the simultaneous detection of beef, buffalo, chicken, cat, dog, pork, and fish in raw and heat-treated food products. Journal Agricultural and Food Chemistry, 67, 8268-8278. 10.1021/acs.jafc.9b02518

Hsieh, C., Chang, W., Chang, H. C., Hsieh, H., Chung, Y., \& Hwang, D. (2010). Puffer fish-based commercial fraud identification in a segment of cytochrome $b$ region by PCR-RFLP analysis. Food Chemistry, 121, 1305-1311. https://doi.org/10.1016/j.foodchem.2010.02.004

Karabasanavar, N. S., Singh, S. P., Kumar, D., \& Shebannavar, S. N. (2014). Detection of pork adulteration by highly-specific PCR assay of mitochondrial D-loop. Food Chemistry, 145, 530-534. https://doi.org/10.1016/j.foodchem.2013.08.084

Kesmen, Z., Gulluce, A., Sahin, F., \& Yetim, H. (2009). Identification of meat species by TaqMan-based real-time PCR assay. Meat Science, 82, 444-449. https://doi.org/10.1016/j.meatsci.2009.02.019

Kesmen, Z., Sahin, F., \& Yetim, H. (2007). PCR assay for the identification of animal species in cooked sausages. Meat Science, 77, 649-653. https://doi.org/10.1016/j.meatsci.2007.05.018 
Khallaf, A. G., Ardura, A., Mohammed-Geba, K., Borrell, Y. J., \& Garcia Vazquez, E. (2014). DNA barcoding reveals a high level of mislabeling in Egyptian fish fillets. Food Control, 46, 441-445. https://doi.org/10.1016/j.foodcont.2014.06.016

Lambert, J. H. (1760). Photometria, sive de mensure et gradibus luminis, colorum et umbrae. German: German Edition, v. 2.

Marcelino, F. C., Guimarães, M. F. M., \& De-Barros, E. G. (2008). Detection and quantification of Roundup Ready® soybean residues in sausage samples by conventional and real-time PCR. Ciência e Tecnologia de Alimentos, 28, 38-45. https://doi.org/10.1590/S0101-20612008000500007

Masi, P., Zeuli, P. L. S., \& Domini, P. (2003). Development and analysis of multiplex microsatellite markers sets in common bean (Phaseolus vulgaris L.). Molecular Breeding, 11, 303-313. https://doi.org/10.1023/A:1023443109985

Mayer, H. K. (2005). Milk species identification in cheese varieties using electrophoretic chromatographic and PCR techniques. International Dairy Journal, 15, 595-604. https://doi.org/10.1016/j.idairyj.2004.10.012

Mousavi, S. M., Khaniki, G. J., Eskandari, S., Rabiei, M., Samiee, S. M., \& Mehdizadeh, M. (2015). Applicability of species-specific polymerase chain reaction for fraud identification in raw ground meat commercially sold in Iran. Journal of Food Composition and Analysis, 40, 47-51. https://doi.org/10.1016/j.jfca.2014.12.009

Mueller, S., Handy, S. M., Deeds, J. R., George, G. O., Broadhead, W. J., Pugh, S. E., \& Garrett, S. D. (2015). Development of a COX1 based PCR-RFLP method for fish species identification. Food Control, 55, 39-42. https://doi.org/10.1016/j.foodcont.2015.02.026

Nunes, E. S. C. L., Franco, R. M., Mársico, E. T., \& Neves, M. S. (2012). Microbiologic and physical-chemical qualities of salted and dried pirarucu (Arapaima gigas Shing, 1822) sold in retail markets. Revista Instituto Adolfo Lutz, 71, 520-529.

Oliveira, A. C. S., Ferreira, B. C. A., Cardoso, G. V. F., Silva, C. L., Silva, A. S., Silva, F., ... Moraes, C.M. (2015). Evaluation of a multiplex PCR for detection of a fraud in the minced beef meat by adding buffalo meat. Revista do Instituto Adolfo Lutz, 74, 371-379.

Paiva, F. C. (2015). Production of arapaima protein hydrolysate using Aspergillusflavo-furcatis protease and pancreatin. Pesquisa Agropecuária Tropical, 45, 89-96. https://doi.org/10.1590/1983-40632015v4529838.

Rosa, K. R., Nornberg, J. L., Silva, K. S., \& Kubota, E. H. (2020). Pirarucu: from its origins to commercial breeding. Brazilian Journal of Development, 6, 6586-6598. https://doi.org/10.34117/bjdv6n2-091

Safdar, M., \& Junejo, W. (2015). A multiplex-conventional PCR assay for bovine, ovine, caprine and fish species identification in feedstuffs: Highly sensitive and specific. Food Control, 50, 190-194. https://doi.org/10.1016/j.foodcont.2014.08.048 


\section{Macrothink}

Journal of Agricultural Studies

ISSN 2166-0379

2020, Vol. 8, No. 2

Santos-Cipriano, F. (2015). Apparent digestibility of energetic ingredients by pirarucu juveniles, Arapaima gigas (Schinz, 1822). Latin American Journal of Aquatic Research, 43, 786-791. https://doi.org/10.3856/vol43-issue4-fulltext-18

Sultana, S., Hossain, M. A. M., Zaidul, I. S. M., \& Ali, M. E. (2018). Multiplex PCR to discriminate bovine, porcine, and fish DNA in gelatin and confectionery products. LWT Food Science and Technology, 92,169-176. https://doi.org/10.1016/j.1wt.2018.02.019

Sumathi, G., Jeyasekaran, G., Shakila, R. J., Sivaraman, B., Arunkumar, G., .... Sukumar, D. (2015). Molecular identification of grouper species using PCR-RFLP technique. Food Control, 51, 300-306. https://doi.org/10.1016/j.foodcont.2014.11.026

Tisza, A., Csikós, A., Simon, A., Gulyás, G., Jávor, A., \& Czeglédi, L. (2016). Identification of poultry species using polymerase chain reaction-single strand conformation polymorphism (PCR-SSCP) and capillary electrophoresis-single strand conformation polymorphism $\begin{array}{lllll}\text { (CE-SSCP) } \quad \text { methods. } & \text { Food } & \text { 430-438. }\end{array}$ https://doi.org/10.1016/j.foodcont.2015.06.006

\section{Copyright Disclaimer}

Copyright for this article is retained by the author(s), with first publication rights granted to the journal.

This is an open-access article distributed under the terms and conditions of the Creative Commons Attribution license (http://creativecommons.org/licenses/by/4.0/). 